\title{
STRATYGRAFICZNE I PRZESTRZENNE ASPEKTY ZRÓŻNICOWANIA SKŁADU CHEMICZNEGO PÓŹNOPLEJSTOCEŃSKICH SEKWENCJI LESSOWO-GLEBOWYCH W POLSCE - PRZYKLADY PROFILI W TYSZOWCACH I BIALYM KOŚCIELE
}

\author{
The stratigraphic and spatial aspects of the differentiation of the chemical \\ composition of the Late Pleistocene loess-palaeosol sequences in Poland \\ - a case study of the Tyszowce and Biały Kościól profiles
}

\author{
JACEK SKURZYŃSKI*, ZDZISŁAW JARY*, JERZY RACZYK*, \\ PIOTR MOSKA ${ }^{\star \star}$, MARCIN KRAWCZYK ${ }^{\star}$
}

\begin{abstract}
Zarys treści. Artykuł prezentuje porównanie składu geochemicznego i stopnia zwietrzenia chemicznego dwóch późnoplejstoceńskich sekwencji lessowo-glebowych, zlokalizowanych w SE i SW Polsce. Analiza chemiczna w zakresie pierwiastków głównych ( $\mathrm{Si}, \mathrm{Al}, \mathrm{Fe}, \mathrm{Mn}, \mathrm{Mg}, \mathrm{Ca}, \mathrm{Na}, \mathrm{K}, \mathrm{Ti}, \mathrm{P}$ ) oraz wyliczonych na ich podstawie wskaźników (CIA, Ti/Al, K/Al, Mg/Ca, $\mathrm{K} / \mathrm{Ca}, \mathrm{Na} / \mathrm{K}$ oraz $\mathrm{Si} / \mathrm{Al}$ ) wykazała, że obie sekwencje są zróżnicowane zarówno w ujęciu stratygraficznym, jak i przestrzennym. Zmienność stratygraficzna związana jest ze zmianami paleoklimatu warunkującymi natężenie zarówno procesów lito-, jak i pedogenezy. Zmienność przestrzenna może wynikać m.in. z odmiennych warunków klimatycznych w trakcie tworzenia się sekwencji lessowo-glebowych, recyklingu lessów lub nawet odmiennego źródła materiału. Istotna może być też dysproporcja miąższości sekwencji, skutkująca zróżnicowanym wpływem infiltracji wód opadowych.
\end{abstract}

Słowa kluczowe: less, gleba kopalna, geochemia, wskaźniki wietrzeniowe, metoda chemostratygraficzna

\begin{abstract}
The article presents the comparison of the geochemical composition and the degree of chemical weathering between two Late Pleistocene loess-palaeosol sequences of SE and SW Poland. The results of major element ( $\mathrm{Si}, \mathrm{Al}, \mathrm{Fe}, \mathrm{Mn}$, $\mathrm{Mg}, \mathrm{Ca}, \mathrm{Na}, \mathrm{K}, \mathrm{Ti}, \mathrm{P}$ ) and geochemical index (CIA, Ti/Al, $\mathrm{K} / \mathrm{Al}, \mathrm{Mg} / \mathrm{Ca}, \mathrm{K} / \mathrm{Ca}, \mathrm{Na} / \mathrm{K}$ oraz Si/Al) analyses indicate stratigraphical and spatial differentiation between sequences. The stratigraphic differentiation is connected with palaeoclimatic conditions which control the intensity of pedogenesis. The spatial variability may be attributed to different climatic conditions during the deposition of loess, the loess recycling process, or even to different source areas. The disproportion between the thicknesses of the loess covers can also be important. It can affect the rainwater infiltration effect.
\end{abstract}

Keywords: loess, palaeosol, geochemistry, weathering indices, chemostratigraphic method

\section{Wstęp}

Sekwencje lessowo-glebowe zawierają jeden z najdokładniejszych lądowych zapisów zmian klimatycznych zachodzących w czwartorzędzie (np. Kukla 1970, 1975, 1977, 1987; Dodonov 2007; Porter 2007; Rousseau i in. 2007; Muhs 2013; Marković i in. 2015). Wyjątkowa przydatność lessu dla rekonstrukcji klimatycznych polega na tym, że cząstki pyłowe, z których jest zbudowany, deponowane są bezpośrednio $\mathrm{z}$ atmosfery (subaeralnie), zatem profile lessowe pośrednio od- zwierciedlają zmiany niektórych elementów paleoklimatycznych w czasie geologicznym (Jary 2007; Muhs 2007, 2013).

Cechy środowiska i klimatu, w jakim powstawały sekwencje lessowo-glebowe, rekonstruowane są na podstawie różnorodnych danych pośrednich (ang. proxy data). Do tego celu najczęściej używa się gleb kopalnych, wskaźników zmienności składu granulometrycznego, właściwości magnetycznych, badań malakologicznych, palinologicznych i wielu innych, które w połączeniu $\mathrm{z}$ zastosowaniem metod datowania wieku (np. TL, OSL, ${ }^{14} \mathrm{C}$ ) umożliwiają dokonanie, okre-

* Uniwersytet Wrocławski, Instytut Geografii i Rozwoju Regionalnego, Pl. Uniwersytecki 1, 50-137 Wrocław; e-mail: jacek.skurzynski@uwr.edu.pl,zdzislaw.jary@uwr.edu.pl,jerzy.raczyk@uwr.edu.pl,marcin.krawczyk@uwr.edu.pl

** Politechnika Śląska, Instytut Fizyki - Centrum Naukowo Dydaktyczne, ul. Konarskiego 22B, 44-100 Gliwice; e-mail: piotr.moska@polsl.pl 
ślonych w czasie geologicznym, rekonstrukcji klimatyczno-środowiskowych (np. Pye 1995; Muhs 2007, 2013).

W literaturze z zakresu paleogeografii coraz częściej publikowane są wyniki badań składu chemicznego lessów i śródlessowych gleb kopalnych różnej rangi stratygraficznej (np. Taylor i in. 1983; Pye, Johnson 1988; Gallet i in. 1996, 1998; Muhs, Bettis III 2000; Jahn i in. 2001; Muhs i in. 2001, 2003, 2008; Yang i in. 2004, 2006; Buggle i in. 2008, 201; Ujvari i in. 2008; Ahmad, Chandra 2013; Tugulan i in. 2016). Także w polskiej literaturze lessowej, choć w znacznie mniejszym stopniu, są stosowane analizy geochemiczne (np. Łukaszew, Mojski 1968; Maruszczak 1976; Dwucet, Śnieszko 1996; Dwucet 1999; Jary 2007; Łącka i in. 2007; Łanczont i in. 2015a, b; Raczyk $i$ in. 2015). Cytowane prace jednoznacznie wskazują na wysoką rolę analiz geochemicznych w badaniach paleośrodowiskowych późnoplejstoceńskich lessów zarówno w ujęciu przestrzennym, jak i stratygraficznym (Jary 2007; Raczyk i in. 2015).

Skład chemiczny eolicznie deponowanego materiału lessowego jest silnie związany ze składem mineralogicznym obszarów źródłowych. Podlega jednak zmianom wskutek postdepozycyjnych procesów wietrzeniowo-glebowych mobilne pierwiastki są redeponowane, co powoduje relatywne wzbogacenie $\mathrm{w}$ pierwiastki niemobilne (Buggle i in. 2011). Wraz ze wzrostem intensywności procesów glebowych wzrasta stopień zwietrzenia chemicznego (np. Kraus 1999), co upoważnia, w celu weryfikacji wydzieleń stratygraficznych, do zastosowania wskaźników zwietrzenia chemicznego.

W pracy porównano rezultaty badań składu chemicznego dwóch sekwencji lessowo-glebowych zlokalizowanych w Tyszowcach (Grzęda Sokalska) i w Białym Kościele (Wzgórza Niemczańsko-Strzelińskie). Są to obecnie kluczowe profile lessów w Polsce, zawierające względnie pełną sekwencję późnoplejstoceńskich jednostek lito-pedostratygraficznych (Jary 2007). W pracy Raczyka i in. (2015) zwrócono uwagę na odrębność geochemiczną lessów polskich w stosunku do innych obszarów europejskiego pasa lessów. Rezultaty badań opierały się jednak na analizie tylko jednego profilu lessowego (Dankowice) położonego $\mathrm{W}$ obrębie Wzgórz NiemczańskoStrzelińskich (Polska SW), około $3 \mathrm{~km}$ na zachód od stanowiska w Białym Kościele. Nie publikowano do tej pory prac dotyczących przestrzennego zróżnicowania składu chemicznego lessów w Polsce.

\section{Charakterystyka stanowisk badawczych}

Stanowiska badawcze Tyszowce i Biały Kościół zlokalizowane są na linii W-E w odległości około 500 km (rys. 1). Tak duża odległość dzieląca badane sekwencje lessowe pozwoli na odniesienie się do wcześniej zgłaszanych hipotez, że pokrywy lessowe odzwierciedlają współczesne i plejstoceńskie cechy klimatu Polski: kontynentalne na wschodzie i bardziej oceaniczne na zachodzie (Cegła 1972; Jersak 1973; Maruszczak 1991a; Jary 2007).

W celu przedstawienia lessowo-glebowych jednostek stratygraficznych przyjęto nazewnictwo wprowadzone pierwotnie dla lessów chińskich (Kukla, An 1989), w modyfikacji Marković'a i in. (2008, 2015). W obu profilach reprezentowane są sekwencje późnoplejstoceńskie, składające się z pięciu głównych jednostek lito-pedostratygraficznych: dwóch kopalnych pedokompleksów (S1 i L1SS1), dwóch jednostek lessowych (L1LL2 i L1LL1) oraz gleby współczesnej (S0) w stropie.

Pedokompleks S1 jest powszechnie korelowany z 5 morskim stadium izotopowym (Marine Isotopic Stage - MIS; Pisias i in. 1984; Martinson i in. 1987). W polskich schematach stratygraficznych gleba ta jest określana jako nietulisko I (Jersak 1973) lub Gi+GJ1 (Maruszczak 1991b). Lessy L1LL2 (MIS 4; dolny plenivistulian) odpowiadają lessom młodszym Ila (Jersak 1973) oraz lessom młodszym dolnym (LMd - Maruszczak 1991b). Gleba śródlessowa L1SS1 (MIS 3; środkowy plenivistulian) jest korelowana $\mathrm{z}$ glebą komorniki (Jersak 1973) oraz glebą Gi/LMd (Maruszczak 1991b), a lessy L1LL1 (MIS 2) deponowane $\mathrm{w}$ górnym pleniglacjale ostatniego zlodowacenia należy korelować z lessem młodszym IIb (Jersak 1973) oraz lessem młodszym środkowym (LMs) i górnym (LMg; Maruszczak 1991b). Gleba S0 tożsama jest z glebą współczesną (Jersak 1973), czyli glebą GH (Maruszczak 1991b).

\section{Tyszowce}

Profil lessowy w Tyszowcach $\left(\lambda=23^{\circ} 42^{\prime} 45^{\prime \prime}\right.$ $\left.\mathrm{E}, \varphi=50^{\circ} 36^{\prime} 30^{\prime \prime} \mathrm{N}\right)$ znajduje się w regionie lubelskim, w północnej części Grzędy Sokalskiej (Maruszczak 1991a). Grzęda Sokalska to skrajnie zachodni fragment Wyżyny Wołyńskiej (Maruszczak 1972; Kondracki 2002) będący równoleżnikowym garbem zbudowanym $\mathrm{z}$ utworów górnej kredy, przykrytym pokrywą lessową o miąższości 10-30 m. Od północy i południa ograniczona jest wyraź- 
nymi krawędziami morfologicznymi o wysokości przekraczającej $10 \mathrm{~m}$ (Wojtanowicz, Buraczyński 1978). Profil lessowy w Tyszowcach zlokalizowano w wyrobisku czynnej cegielni na wysokości 226 m n.p.m., na skraju wierzchowiny lessowej tuż przy zboczu doliny rzeki Huczwa, 30 m powyżej współczesnego jej dna (rys. 2). Miąższość pokrywy lessowej na obszarze cegielni lokalnie przekracza $20 \mathrm{~m}$.

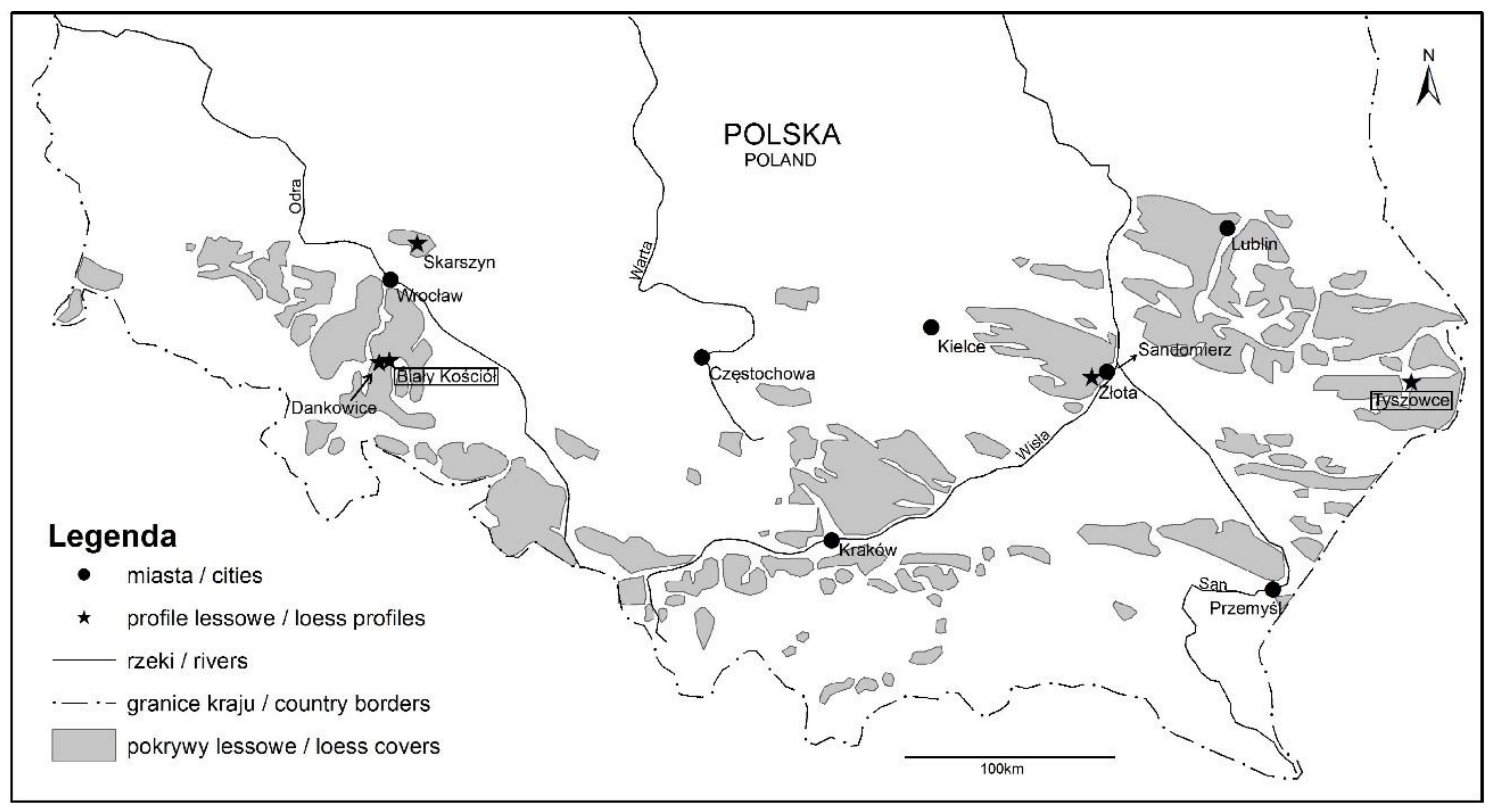

Rys. 1. Lokalizacja obszaru badań na tle polskich pokryw lessowych

Location of the research area against the background of loess covers in Poland

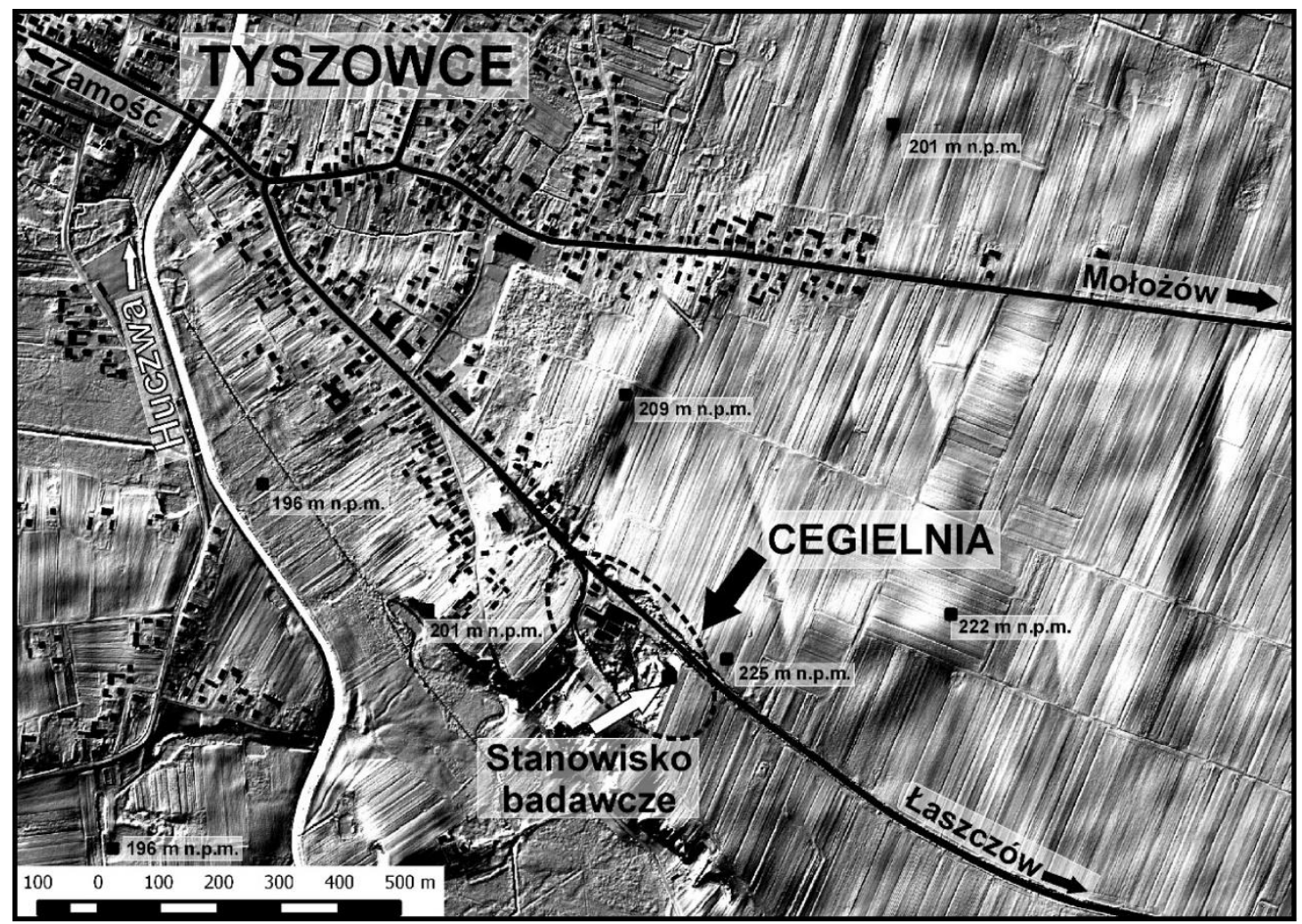

Rys. 2. Lokalizacja profilu lessowego w Tyszowcach

Location of the loess profile in Tyszowce 
Lessy w Tyszowcach zostały po raz pierwszy opisane w pracy Maruszczaka (1974), który wyróżnił w profilu lessowym w TyszowcachMajdanie less młodszy górny $(\mathrm{LMg})$ ze słabymi oznakami dwudzielności oraz sedymentem glebowym w spągu, less młodszy środkowy o cechach sedymentu glebowego oraz less młodszy dolny i najniższy z oznakami rozwoju procesów glebotwórczych. Poniżej cytowany autor udokumentował dobrze rozwiniętą glebę interglacjalną z poziomami genetycznymi charakterystycznymi dla kopalnej gleby płowej. Gleba ta wytworzyła się na lessie piaszczystym.

Badania Maruszczaka (1974) uszczegółowili rok później Buraczyński i Wojtanowicz (1975), którzy wyróżnili w profilu dwie gleby kopalne rozdzielone i przykryte lessem. Młodszej, silnie oglejonej glebie genezy tundrowej przypisali rangę interstadialną. Starsza gleba, $\mathrm{z}$ bardzo dobrze wykształconym iluwium, została określona jako gleba rangi interglacjalnej. $\mathrm{W}$ stropie tej gleby występował poziom próchniczny wykazujący ślady przemieszczenia i zaburzenia kriogeniczne $\mathrm{w}$ formie pseudomorfoz po sezonowym lodzie gruntowym.

W 2000 roku przeprowadzono szczegółowe badania litostratygraficzne późnoplejstoceńskich lessów w cegielni w Tyszowcach, a ich rezultaty zostały opublikowane przez Jarego (2007). W sekwencji lessów wydzielono dwie główne fazy depozycji pyłu lessowego, które skorelowano $\mathrm{z}$ dolnym $\mathrm{i}$ górnym pleniglacjałem ostatniego zlodowacenia. Stwierdzono również sześć poziomów struktur peryglacjalnych.

Nowy profil lessów w cegielni w Tyszowcach został przygotowany w listopadzie 2012 roku. Późnoplejstoceńska sekwencja lessowoglebowa o wysokości $19 \mathrm{~m}$ została szczegółowo udokumentowana oraz opróbkowana $\mathrm{w}$ interwale co $5 \mathrm{~cm}$. Przeprowadzone badania pozwolity na stwierdzenie, że sekwencja lessowo-glebowa w Tyszowcach zawiera prawdopodobnie jeden z najbardziej szczegółowych pośrednich zapisów zmian klimatyczno-środowiskowych w lessach polskich (Jary, Mroczek (red.) 2014; Jary i in. 2014; Moska i in. 2014). Dokładny opis litopedologiczny przedstawiono w pracy Moski i in. (2017).

W świetle przeprowadzonych badań (Jary, Mroczek (red.) 2014; Jary i in. 2014; Moska i in. 2014) późnoplejstoceńska sekwencja lessowoglebowa w Tyszowcach jest zbudowana z pięciu jednostek lito-pedostratygraficznych: dwóch poligenetycznych kompleksów glebowych (S1 oraz L1SS1), dwóch jednostek lessowych (L1LL1 i L1LL2) oraz gleby współczesnej S0.

Pedokompleks S1 (korelowany z MIS 5) składa się z dwóch nałożonych na siebie czarnoziemowych poziomów humusowych (wczesny vistulian) oraz dobrze wykształconego, strukturalnego poziomu B utworzonego na pylasto-piaszczystym substracie (interglacjał eemski).

Dolna jednostka lessowa L1LL2 (MIS 4) jest w spągu wyraźnie smugowana (zawiera wkładki humusu) i oglejona. Jej cechy litologiczne wskazują na eoliczną depozycję oraz synchronicznie przebiegające procesy redepozycyjne po nachylonej powierzchni. Górna część lessów L1LL2 została przekształcona przez procesy glebowe związane $\mathrm{z}$ formowaniem się gleby kopalnej L1SS1. W lessach L1LL2 stwierdzono obecność pseudomorfoz klinów lodowych (Jary 2007, 2009), które są dowodem rozwoju i degradacji wieloletniej zmarzliny.

Gleba kopalna L1SS1 (MIS 3) rozdziela dwie główne fazy depozycji lessów w ostatnim glacjale. W profilu Tyszowce jest reprezentowana przez słabo wykształcony horyzont typu cambic oraz 1-3 nałożone poziomy tundro-glejowe, zdeformowane przez procesy krioturbacji i geliflukcji.

Gleba kopalna L1SS1 w Tyszowcach przykryta jest bardzo miąższym lessem L1LL1 (14 $\mathrm{m})$, co jest dowodem niezwykle wysokiego tempa depozycji lessów w górnym plenivistulianie (MIS 2). W jednostce L1LL1 dominują litofacje lessów smugowanych i laminowanych - lessy masywne pojawiają się bardzo rzadko. W środkowej i górnej części powszechnie występują laminy piaszczyste, sugerujące krótkotrwałe epizody transportu materiału z pobliskiej doliny Huczwy. Dwie generacje różnowiekowych pseudomorfoz klinów lodowych wskazują na dwukrotny rozwój oraz degradację wieloletniej zmarzliny $w$ trakcie sedymentacji lessów L1LL1.

\section{Biały Kościól}

Odsłonięcie lessów w Białym Kościele $(\lambda=$ 1701'30" E, $\varphi=50^{\circ} 43^{\prime} 30^{\prime \prime}$ N,185 m n.p.m.) położone jest $\mathrm{w}$ regionie dolnośląskim (Maruszczak 1991a), w obrębie Wzgórz NiemczańskoStrzelińskich. Mezoregion ten stanowi wyżynną część Przedgórza Sudeckiego (Kondracki 2002) zbudowaną ze skał krystalicznych częściowo pokrytych pylastymi osadami genezy eolicznej. Lessy i osady lessopochodne występują tutaj w postaci nieciągłych pokryw o miąższości od 
kilku do 12 m (Jary i in. 2002). Stanowisko badawcze znajduje się w nieczynnej gliniance na zboczu o ekspozycji północnej, u wylotu dolinki bezimiennego cieku do doliny Oławy w jej środkowym odcinku. Wyrobisko znajduje się w odległości 20-30 metrów od drogi łączącej Strzelin z Henrykowem (rys. 3).

Pełną sekwencję lessową profilu w Białym Kościele po raz pierwszy scharakteryzowano w pracy Ciszka i in. (2001). Rezultaty później- szych multidyscyplinarnych badań zostały opublikowane w licznych publikacjach naukowych (Jary i in. 2002, 2004; Fedorowicz 2005, 2006; Jary 2007, 2009, 2010; Komar i in. 2009; Moska i in. 2011, 2012; Jary, Ciszek 2013). W świetle cytowanych prac sekwencja lessowo-glebowa w Białym Kościele składa się z tych samych jednostek pedo- i litostratygraficznych co profil w Tyszowcach.

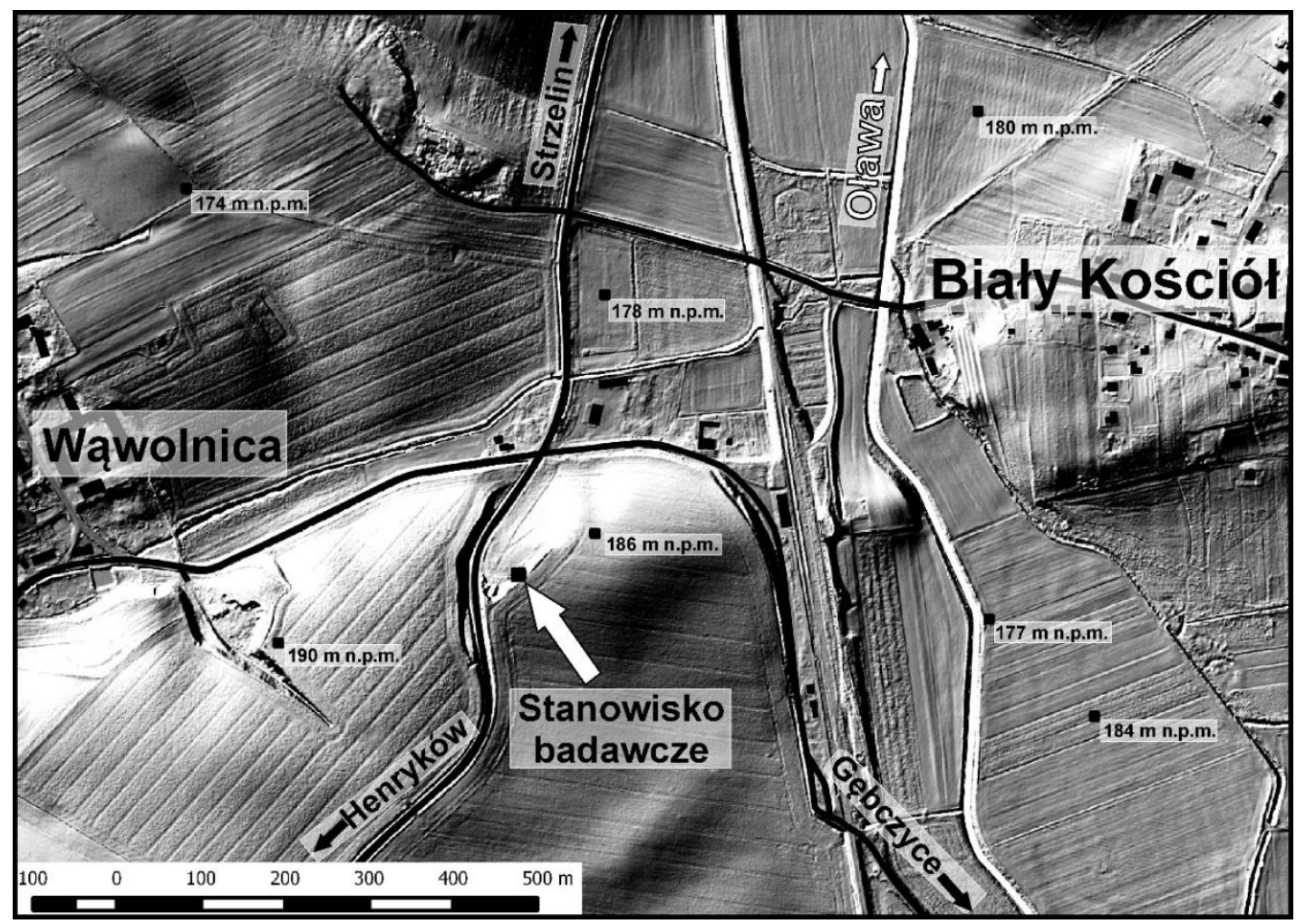

Rys. 3. Lokalizacja profilu lessowego w Białym Kościele

Location of the loess profile in Biały Kośció1

Badania terenowe profilu lessowego w Białym Kościele ponowiono w 2008 roku. W pionowej ścianie 9-metrowego odsłonięcia ponownie zarejestrowano pełną sekwencję późnoplejstoceńskich osadów, składającą się z pięciu głównych jednostek. Dokładny opis litologiczny przedstawiono w pracy Jarego i in. (2014).

Poligenetyczny zespół gleb kopalnych S1 (MIS 5) w Białym Kościele składa się z miąższego poziomu iluwialnego Bt, rozwiniętego na heterogenicznym piaszczysto-pyłowym substracie, poziomu eluwialnego Et i akumulacyjnego A. Ważnym markerem tej pedojednostki jest podpoziom przejściowy $\mathrm{AE} \mathrm{z}$ nagromadzeniem węgielków drzewnych. W profilu zespołu gleb kopalnych można obserwować powierzchnie erozyjne i/lub deformacyjne świadczące o skom- plikowanej historii rozwoju, zakończonej przekształceniem stropowych partii przez procesy glejowe i krioturbacyjne.

Powyżej jednostki S1 zalega około 1,5-metrowy poziom lessów L1LL2. Tak dobrze rozwinięta jednostka rzadko występuje w lessowych profilach południowo-zachodniej Polski (Jary 2007) - jest to charakterystyczną cechą sekwencji lessowej z Białego Kościoła. W jej stropie wykształciła się gleba (pedokompleks) L1SS1. W Białym Kościele jest ona zbudowana z nałożonych poziomów akumulacyjnych gleb glejowo-tundrowych, zalegających na zdegradowanym poziomie typu cambic. Strop gleby został zdeformowany przez procesy pęcznienia mrozowego i geliflukcji. 
Powyżej gleby L1SS1 występuje rozbudowana jednostka lessowa L1LL1, wykazująca znaczne zróżnicowanie w profilu. Na uwagę zasługuje słabo zaznaczająca się gleba tundrowo-glejowa w spągowej części lessów L1LL1, poziomy deformacji peryglacjalnych oraz kilka horyzontów inicjalnego oglejenia. Jary (2007) uważa, że są one dowodem nierównomiernego tempa depozycji lessu i zmiennych warunków klimatycznych w trakcie MIS 2. W stropie lessów L1LL1 wykształciła się współczesna gleba brunatna S0.

\section{Material i metody badawcze}

W trakcie prac terenowych starannie przygotowano wyczyszczone pionowe ściany, które opisano pod kątem sedymentologii i stratygrafii. Po wykonaniu opisu przystapiono do poboru materiału. W obu przypadkach pionowy interwał próbkowania wynosił $5 \mathrm{~cm}$, jednak do analizy składu chemicznego wytypowano tylko niektóre z próbek - liczbę oznaczeń zagęszczano w sąsiedztwie granic litologicznych. Dla profilu w Tyszowcach wykonano łącznie 85 oznaczeń, a dla Białego Kościoła - 48 .

Skład chemiczny oznaczono zgodnie z metodyką wprowadzoną do polskiej literatury lessowej przez Raczyka (Raczyk i in. 2015). Wytypowane do oznaczeń składu chemicznego próbki suszono w temperaturze $105^{\circ} \mathrm{C}$ przez okres $24 \mathrm{~h}$. Roztarte w moździerzu agatowym naważki suchego materiału (5 g) wyprażono $\mathrm{w}$ piecu muflowym $\left(1000^{\circ} \mathrm{C} / 1 \mathrm{~h}\right) \mathrm{w}$ celu określenia straty prażenia (loss on ignition - LOI). Z każdej wyprażonej próbki, po ponownym roztarciu $\mathrm{w}$ moździerzu agatowym, pobrano $250 \mathrm{mg}$ materiału, zmieszano z topnikiem (czteroboran sodu) i umieszczono w platynowym tygielku. Tak przygotowany materiał stopiono w piecu muflowym $\left(1000^{\circ} \mathrm{C} / 5 \mathrm{~min}\right)$. $\mathrm{W}$ rezultacie, po ostudzeniu, otrzymano szkliste „pastylki”, które zalano $10 \% \mathrm{HCl}$ w celu całkowitego rozpuszczenia. Powstałe roztwory zostały rozcieńczone wodą destylowaną do objętości 250 $\mathrm{ml}$. Właściwa analiza składu chemicznego wykonana została metodą atomowej spektrometrii absorpcyjnej (AAS) - oznaczono w ten sposób sód $(\mathrm{Na})$, potas $(\mathrm{K})$, magnez $(\mathrm{Mg})$, wapń $(\mathrm{Ca})$, żelazo $(\mathrm{Fe})$, mangan $(\mathrm{Mn})$, glin (Al) oraz tytan (Ti). Fosfor (P) określony został kolorymetrycznie, po wcześniejszej mineralizacji $\mathrm{w}$ mineralizatorze mikrofalowym. Wszystkie otrzymane stężenia dla danej próbki przeliczono na tlenki, bez uwzględnienia składników lotnych. Krzemionki nie oznaczano, przyjmując, że stanowi dopełnienie do
$100 \%$. Oznaczenia zostały potwierdzone analizą certyfikowanych materiałów referencyjnych dla lessów, tj. ISE 934 oraz ISE 974, dostarczonych przez firmę Wepal. Autorzy nie mieli technicznej możliwości wykonania oznaczeń analitycznych zawartości $\mathrm{CaO}^{*}$, czyli wapnia (przeliczonego na tlenek wapnia) wyłącznie z minerałów krzemianowych, niezbędnego do wyliczenia wskaźnika CIA (Chemical Index of Alteration; Nesbitt, Young 1982) definiowanego równaniem CIA = $\left[\mathrm{Al}_{2} \mathrm{O}_{3} /\left(\mathrm{Al}_{2} \mathrm{O}_{3}+\mathrm{CaO} *+\mathrm{Na}_{2} \mathrm{O}+\mathrm{K}_{2} \mathrm{O}\right)\right] * 100$. $\mathrm{CaO}^{*}$ oszacowano zatem zgodnie $\mathrm{z}$ metodą McLennan'a (1993).

\section{Wyniki oznaczeń składu chemicznego}

Zmienność składu chemicznego w profilu pionowym przedstawiono na rys. 4 - dla ułatwienia przyjęto tę samą skalę. Wszystkie tlenki wyrażone są w procentach wagowych (wt\%), bez straty prażenia (LOI). Dla lepszej percepcji głównych poziomów pedo- i litostratygraficznych dodano wykresy molowych stosunków $\mathrm{K} / \mathrm{Ca}$ i $\mathrm{Mg} / \mathrm{Ca}$. Wartości pierwszego $\mathrm{z}$ nich wzrastają $\mathrm{w}$ glebach z powodu intensywnego rozpuszczania węglanów (np. Yang i in. 2004), drugiego zaś z powodu słabszego ługowania magnezu $\mathrm{w}$ stosunku do wapnia (Bokhorst $i$ in. 2009). Pozostałe pochodne wskaźniki geochemiczne, wyliczone na podstawie oznaczonego analitycznie składu chemicznego, zaprezentowane zostaną $\mathrm{w}$ dalszej części pracy.

$\mathrm{W}$ tab. 1 przedstawiono przeciętne wartości oznaczanych pierwiastków (wyrażonych jako tlenki) oraz zakres ich zmienności w Tyszowcach (TYSZ) i Białym Kościele (BK). Na podstawie tych statystyk oraz zmienności przebiegu krzywych głębokościowych (rys. 4) możliwe było rozpoziomowanie stratygraficzne na pięć jednostek lito-i pedostratygraficznych.

Gleba S0 charakteryzuje się bardzo silnym zubożeniem w wapń i magnez, w stosunku do lessów L1LL1, w których stropie się wykształciła. Jest to efekt wyługowania węglanów, powodujący również znaczne obniżenie wartości LOI. W obu sekwencjach obserwujemy wzrost krzemionki, do wartości porównywalnych tylko z glebą S1. Wzrasta też udział glinu, tytanu oraz fosforu. Ten ostatni osiąga w glebie S0 najwyższe wartości. W Białym Kościele, w stosunku do Tyszowców, gleba S0 jest mocno wzbogacona $w$ glin, fosfor i magnez. Nieco więcej ma też sodu. Zawartość tytanu, manganu, żelaza i potasu jest zbliżona, znacznie mniej występuje krzemionki i wapnia. 

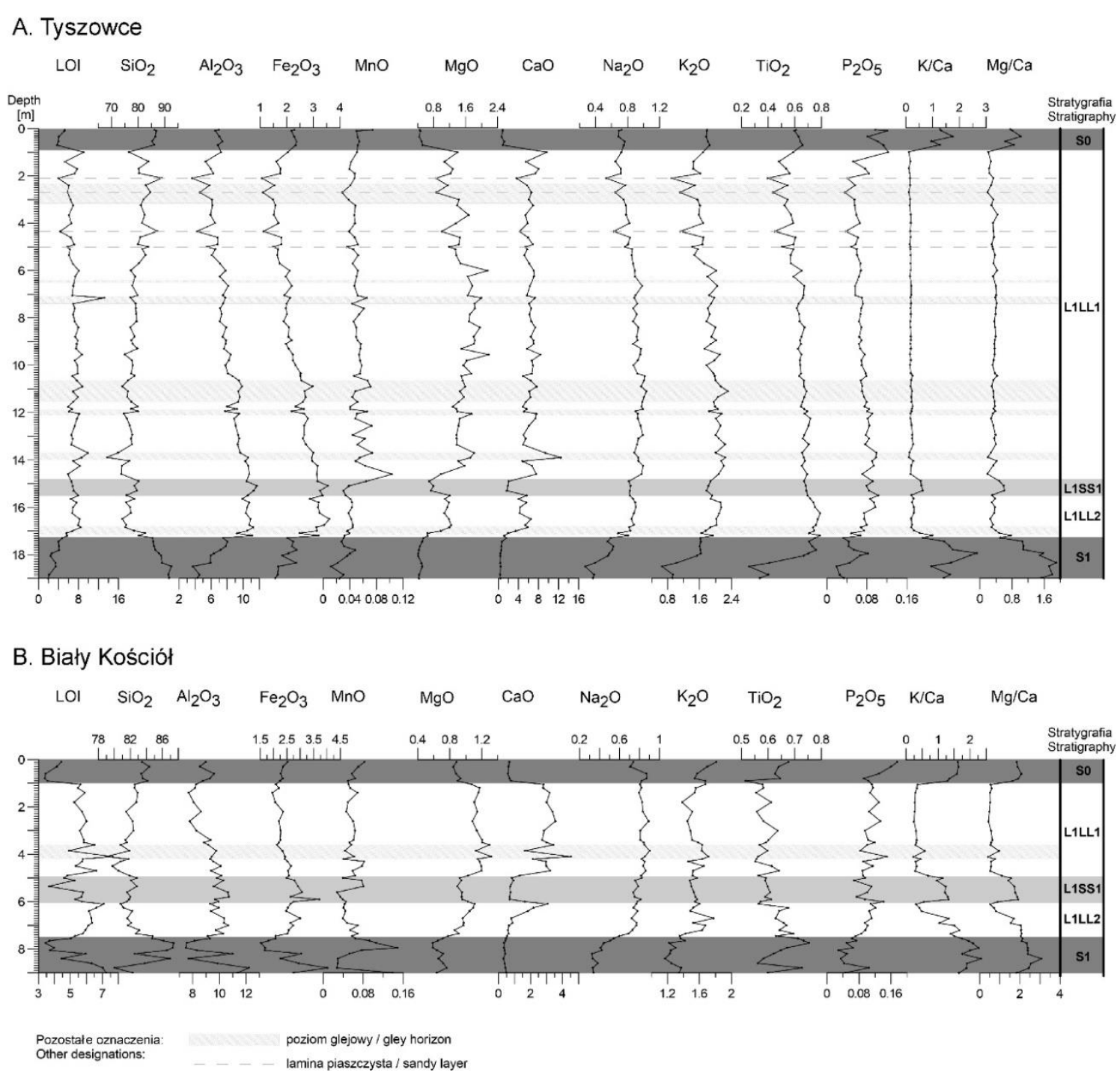

Rys. 4. Zmienność składu chemicznego sekwencji w Tyszowcach i Białym Kościele

The variability of the chemical composition of the sequences in Tyszowce and Biały Kościół

Lessy L1LL1 w obu sekwencjach cechują się najwyższą $\mathrm{w}$ profilu przeciętną zawartością wapnia i magnezu. W Tyszowcach udział tych mobilnych pierwiastków jest jednak znacznie wyższy niż w Białym Kościele, w którym obserwujemy znacznie więcej krzemionki, glinu i fosforu. Wraz z głębokością wzrasta udział glinu i żelaza. W sekwencji w Tyszowcach trend ten jest dużo lepiej widoczny. Jednostka L1LL1 jest silnie zróżnicowana pod względem litologicznym, co rzutuje na jej skład chemiczny. W Tyszowcach, na głębokościach 2,1, 2,7, 4,35 i 5,0 m występują laminy piaszczyste (rys. 4) pobrane z nich próbki cechują się wyraźnym, skokowym obniżeniem zawartości wszystkich składników poza krzemionką. Wyraźnie zaznacza się również wpływ poziomów inicjalnych gleb glejowych (np. Biały Kościół na głębokości od 3,6 do 4,2 m) i/lub deluwiów glebowych (np. Tyszowce od 13,5 do 14,6 m). W dolnej części lessów L1LL1 wzrasta udział glinu i żelaza, pojawiają się także silne wahania innych oznaczanych pierwiastków (rys. 4).

Gleba L1SS1 w obu sekwencjach od sąsiadujących jednostek różni się znacznym obniżeniem zawartości wapnia i magnezu, przy znacznym wzbogaceniu w glin i żelazo.

Lessy L1LL2 wykazują typowe dla poziomów lessowych wzbogacenie w wapń i magnez oraz charakterystyczny dla poziomów glebowych wysoki udział m.in. glinu. Jednostka łączy w sobie zatem cechy zarówno gleb, jak i lessów. Znamienny jest dla niej wzrost udziału tytanu, kontynuujący się aż do górnej części pedokompleksu S1. 


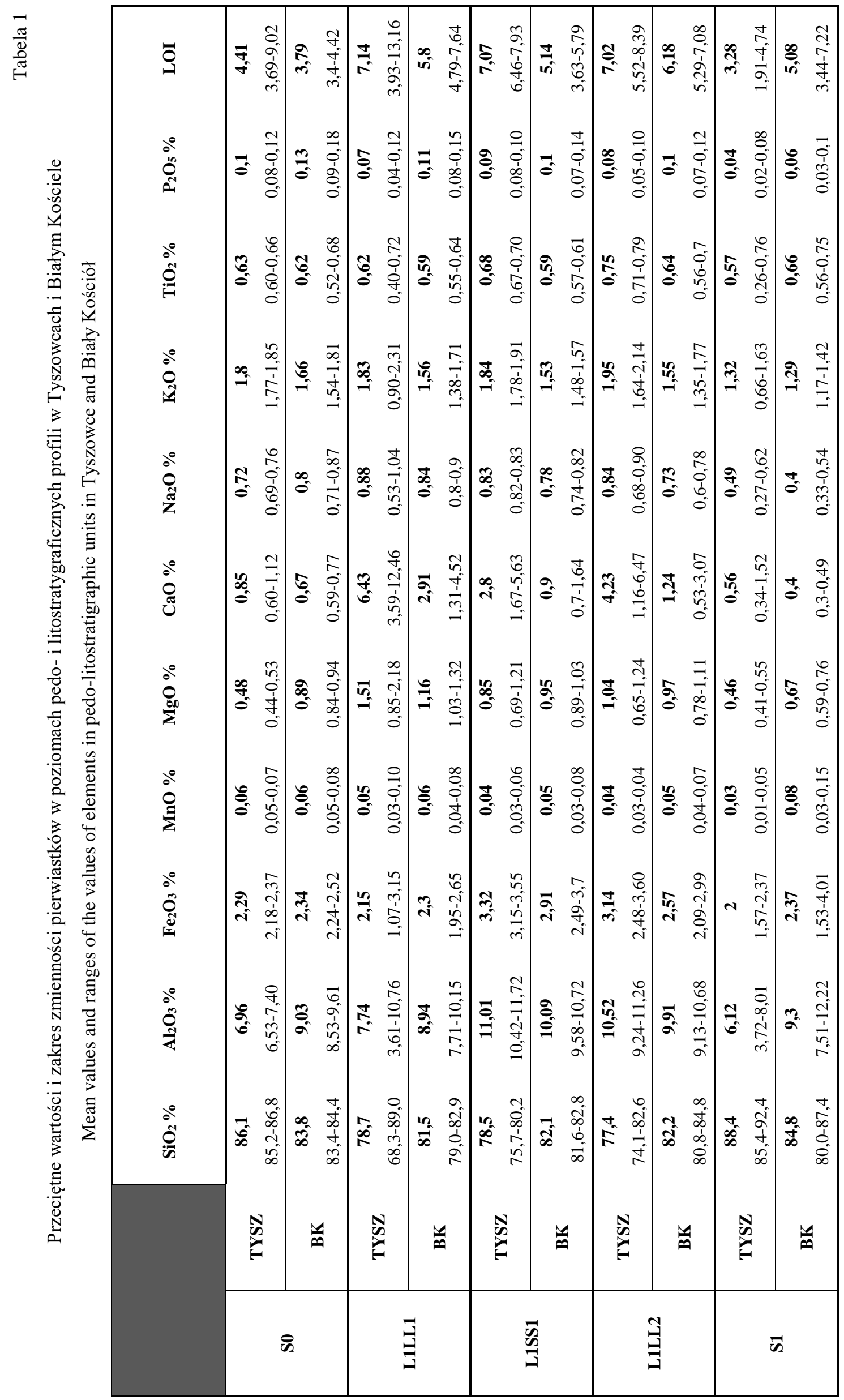


Gleba S1 charakteryzuje się największym przeciętnym udziałem krzemionki, co jest rezultatem zubożenia w pozostałe składniki chemiczne. W Białym Kościele stwierdzono dosyć wysoki jak na tę jednostkę, udział m.in. glinu, żelaza i tytanu. W Tyszowcach przeciętne zawartości wszystkich pierwiastków, poza krzemionką, były najniższe w profilu.

Bardzo ciekawie przedstawia się zróżnicowanie przeciętnych wartości wyliczonych dla całych sekwencji, bez rozróżniania poszczególnych jednostek (tab. 2). W obu przypadkach dominuje krzemionka, której średni udział jest znacznie wyższy od powszechnie przyjętych wartości referencyjnych, takich jak przeciętny skład górnej skorupy kontynentalnej (UCC Upper Continental Crust; Taylor, McLennan 1985) lub globalny przeciętny skład lessów (GAL - Global Average Loess; Ujvari i in. 2008). Wartości pozostałych pierwiastków głównych są zatem relatywnie niskie (tab. 2). Należy zaznaczyć, że wartości GAL wyliczone zostały na podstawie wyłącznie próbek lessów, podczas gdy przeciętne wartości dla Białego Kościoła i Tyszowców podano dla całej sekwencji, łącznie z glebami kopalnymi. Oznacza to, że biorąc pod uwagę wyłącznie jednostki lessowe, dysproporcja pomiędzy GAL a omawianymi stanowiskami badawczymi byłaby znacznie większa.

Tabela 2

Porównanie przeciętnego składu chemicznego w Tyszowcach i Białym Kościele z wartościami GAL i UCC

The comparison of the average chemical composition in the Tyszowce and Biały Kościół profiles with the GAL and UCC values

\begin{tabular}{|c|cccccccccc|}
\hline & $\mathrm{SiO}_{2} \%$ & $\mathrm{Al}_{2} \mathrm{O}_{3} \%$ & $\mathrm{Fe}_{2} \mathrm{O}_{3} \%$ & $\mathbf{M n O} \%$ & $\mathbf{M g O} \%$ & $\mathbf{C a O} \%$ & $\mathrm{Na}_{2} \mathrm{O} \%$ & $\mathrm{~K}_{2} \mathrm{O} \%$ & $\mathrm{TiO}_{2} \%$ & $\mathrm{P}_{2} \mathrm{O}_{5} \%$ \\
\hline BK & 82,66 & 9,38 & 2,46 & 0,06 & 0,96 & 1,55 & 0,71 & 1,51 & 0,62 & 0,10 \\
TYSZ & 80,13 & 7,99 & 2,31 & 0,05 & 1,24 & 4,98 & 0,82 & 1,78 & 0,63 & 0,07 \\
GAL & 70,71 & 11,74 & 3,75 & 0,07 & 2,15 & 6,67 & 1,68 & 2,22 & 0,71 & 0,14 \\
UCC & 66,00 & 15,20 & 5,00 & 0,08 & 2,20 & 4,20 & 3,90 & 3,40 & 0,50 & 0,40 \\
\hline
\end{tabular}

Tyszowce charakteryzują się wysokim udziałem wapnia, wyższym od wartości UCC, przy stosunkowo niskim udziale glinu. Wyższy niż w Białym Kościele jest również przeciętny udział magnezu, sodu i potasu, przy niższym średnim udziale fosforu i żelaza. Zawartość tytanu w obu sekwencjach jest bardzo zbliżona.

\section{Interpretacja}

Sekwencje lessowo-glebowe w Białym Kościele i Tyszowcach pod względem geochemicznym wykazują wyraźne podobieństwo w jakościowym wykształceniu poszczególnych jednostek pedo- i litostratygraficznych. Mocno zaznaczają się jednak ilościowe różnice w zawartościach składników chemicznych. Biały Kościół zubożony jest w mobilne pierwiastki (np. wapń), przy wzbogaceniu w pierwiastki niemobilne (np. glin). Zdaniem Buggle i in. (2011) wskazuje to na typowy efekt działania postdepozycyjnych procesów wietrzeniowo-glebowych. Różnice w przeciętnym składzie chemicznym już na etapie wstępnej analizy mogą sugerować, że procesy glebotwórcze w Białym Kościele były inten- sywniejsze niż w Tyszowcach. Wraz ze wzrostem intensywności procesów glebowych rośnie stopień zwietrzenia chemicznego (np. Kraus 1999), który najczęściej jest określany ilościowo za pomocą wskaźnika CIA. Zmienność stopnia zwietrzenia chemicznego, wyrażonego wskaźnikiem CIA, przedstawiono graficznie na trójkątnych diagramach A-CN-K (rys. 5; Nesbitt, Young 1984). Wartości CIA wzrastają zgodnie z opisem osi $\mathrm{Al}_{2} \mathrm{O}_{3}$. Zaznaczono dodatkowo wartość $\mathrm{CIA}=65$, stanowiącą przyjętą granicę pomiędzy utworami słabo i średnio zwietrzałymi chemicznie (np. Song i in. 2014).

W świetle przeprowadzonych badań sekwencja w Tyszowcach jest wyraźnie dwudzielna. Glebę S0 oraz większość lessów L1LL1 (do głębokości 13,5 m) można zaklasyfikować do utworów słabo zwietrzałych chemicznie $(C I A<65)$. Najniższą część lessów L1LL1, opisaną w terenie jako deluwia glebowe $(13,5-14,6$ $\mathrm{m})$, oraz pozostałą część profilu zaliczyć należy do umiarkowanego stopnia zwietrzenia chemicznego. W poziomie humusowym gleby L1SS1 stwierdzono najwyższe wartości CIA około 71. Stopień zwietrzenia gleby S1 prawdo- 
podobnie jest zaniżony ze względu na duże domieszki lokalnego materiału piaszczystego, który może wpływać na wartości CIA (np. Nesbitt, Young 1982; Shao i in. 2012). W Białym Kościele praktycznie cała sekwencja cechuje się średnim stopniem zwietrzenia chemicznego (CIA $>65)$. $\mathrm{Na}$ wykresach A-CN-K dla obu sekwencji (rys. 5) widać wyraźnie zróżnicowanie na poszczególne jednostki. Punkty odpowiadające glebie S1 tworzą odrębną chmurę, co wskazuje na odmienny

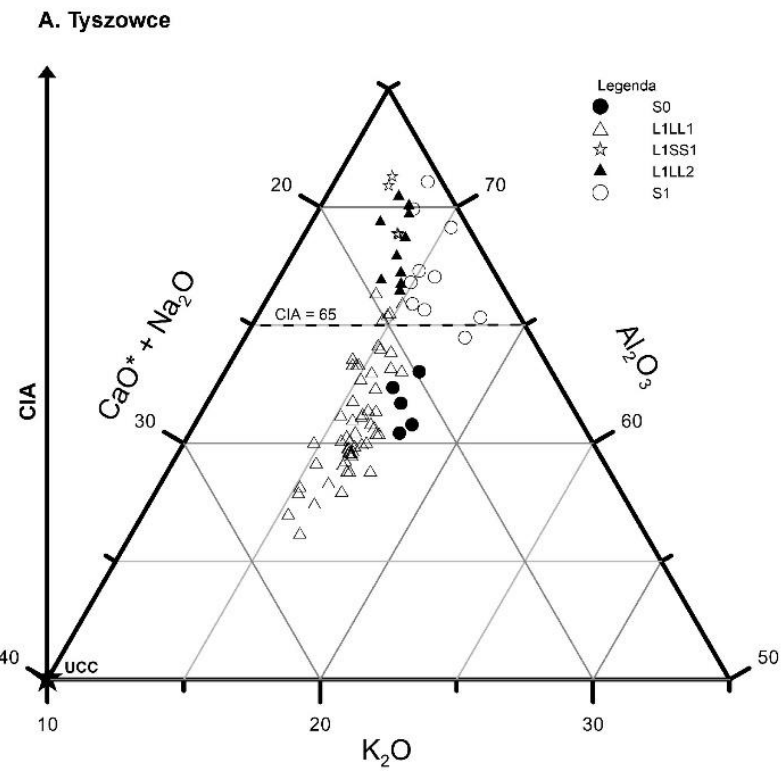

materiał źródłowy. Lessy L1LL2 i gleba L1SS1 cechują się podobnym stopniem zwietrzenia chemicznego. Najsłabiej zwietrzałe są lessy L1LL1. Jak pokazały badania Kemp'a (2001), Jeong'a i in. (2008) i Mroczka (2013) nawet „świeże" lessy ulegają bioturbacji i słabemu wietrzeniu po depozycji, mogą zawierać cząstki erodowane i przemieszczone ze starszych gleb. Jest to dobrze widoczne w poziomie deluwiów.

\section{B. Biały Kościól}

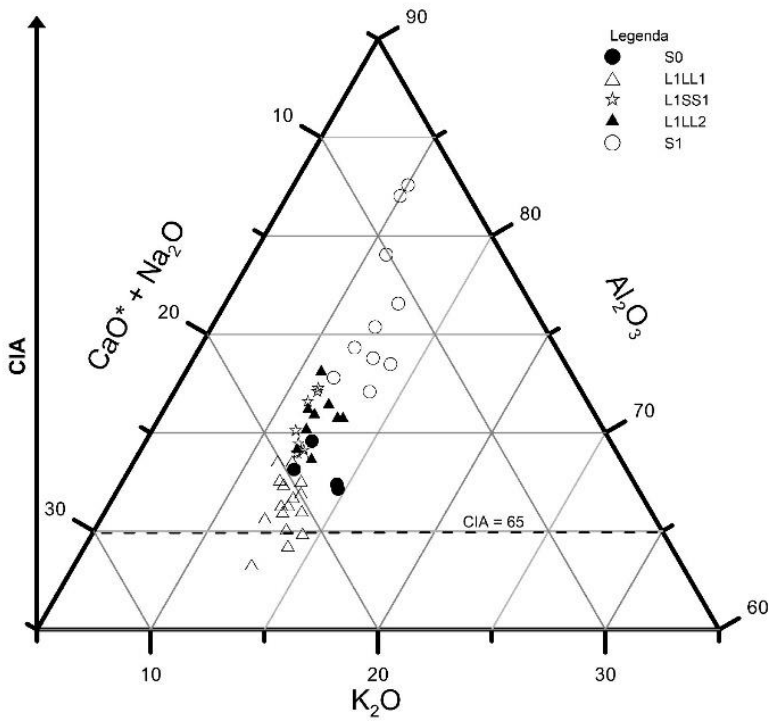

Rys. 5. Stopień zwietrzenia chemicznego (CIA) sekwencji w Tyszowcach i Białym Kościele

The chemical weathering degree (CIA) of the sequences in Tyszowce and Biały Kościół

Stopień zwietrzenia chemicznego oparty na CIA dla potwierdzenia zestawiono $\mathrm{z}$ molowym stosunkiem $\mathrm{Na} / \mathrm{K}$ (rys. 6), który również może być stosowany jako wskaźnik zwietrzenia osadów (Chen i in. 2008; Song i in. 2014). Bogate w sód plagioklazy są o wiele bardziej podatne na wietrzenie niż zasobne $\mathrm{w}$ potas skalenie potasowe, dlatego stosunek $\mathrm{Na} / \mathrm{K}$ jest odwrotnie proporcjonalny do stopnia zwietrzenia chemicznego (Chen i in. 2008). W Tyszowcach korelacja pomiędzy $\mathrm{Na} / \mathrm{K}$ a CIA wyniosła $-0,64$ a w Białym Kościele -0,84. Najważniejszą różnicą pomiędzy zastosowanymi wskaźnikami jest stopień zwietrzenia gleby współczesnej. Bazując na CIA, przyjąć należy, że gleba współczesna wykazuje znacznie mniejsze zwietrzenie od pozostałych jednostek glebowych, podczas gdy według $\mathrm{Na} / \mathrm{K}$ jest prawie tak mocno zwietrzała, jak pedokompleks S1.

Na podstawie dwóch wskaźników zwietrzenia chemicznego wykazano, że sekwencja lessowo-glebowa w Białym Kościele jest bardziej zwietrzała chemicznie niż profil w Tyszowcach. Zależność tę spełniają nawet lessy L1LL1, najlepiej odzwierciedlające charakter materiału źródłowego. Przyjmuje się, że CIA w zakresie 50-65 odpowiada słabemu zwietrzeniu chemicznemu w chłodnym i suchym klimacie, a wartości 65-85 reprezentują ciepłe i wilgotne warunki paleoklimatyczne (np. Song i in. 2014). Nie jest oczywiście możliwe, aby jednostki lessowe kształtowały się $\mathrm{w}$ warunkach ciepłego i wilgotnego klimatu. Możliwe jednak, że większe zwietrzenie chemiczne stanowi wypadkową nieco łagodniejszego klimatu i tzw. recyklingu materiału lessowego (van Loon 2006). Nawet lessy L1LL1 mogą być częściowo zbudowane ze starszego, pochodzącego ze zniszczonych pokryw lessowych, materiału (Mroczek 2013), który mógł być transportowany w kierunku wschodnim razem ze świeżym materiałem, co skutkować mogłoby wyższymi wartościami CIA w lessach L1LL1 Białego Kościoła. Przy takim założeniu mniejsze przeciętne zwietrzenie les- 
sów L1LL1 w Tyszowcach byłoby wynikiem lokalizacji bliżej obszaru źródłowego, co ograniczałoby modyfikację składu chemicznego wynikającą z domieszki starszego materiału. Założenie takie mogłoby znaleźć potwierdzenie w różnicach przeciętnych wartości molowego stosun$\mathrm{ku} \mathrm{SiO}_{2} / \mathrm{Al}_{2} \mathrm{O}_{3}$.Wskaźnik ten maleje wraz ze wzrostem odległości od obszaru źródłowego

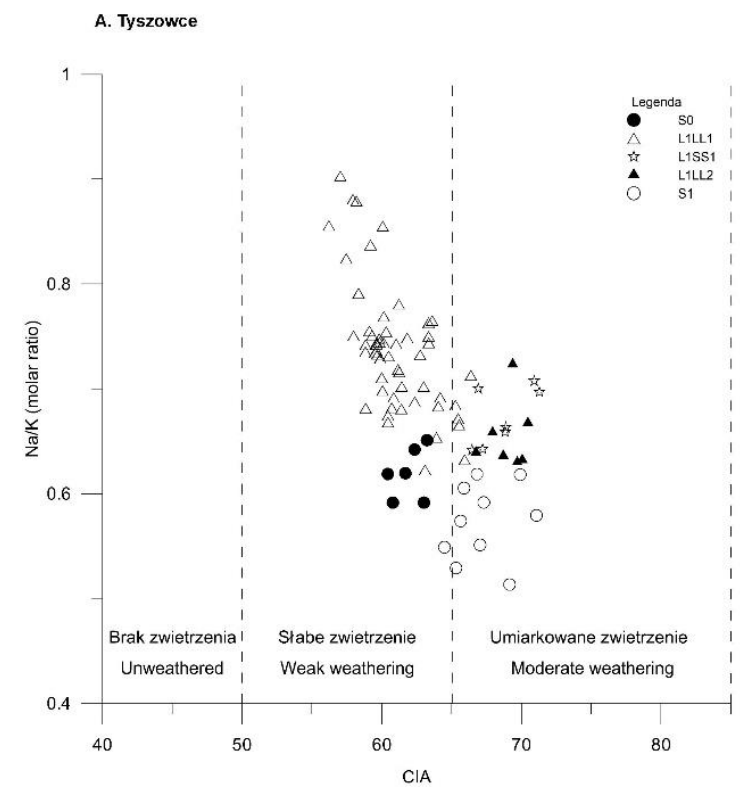

(Guan i in. 2016). Mają na to wpływ dwa czynniki: niewielka mobilność krzemionki i glinu w trakcie pedogenezy oraz efekt wysortowania granulometrycznego - w grubszych frakcjach dominuje krzemionka, a w drobnych glin (Hao i in. 2010; Guan i in. 2016). W Tyszowcach przeciętna wartość Si/Al w lessach L1LL1 wyniosła 18,4 a w Białym Kościele 15,8.

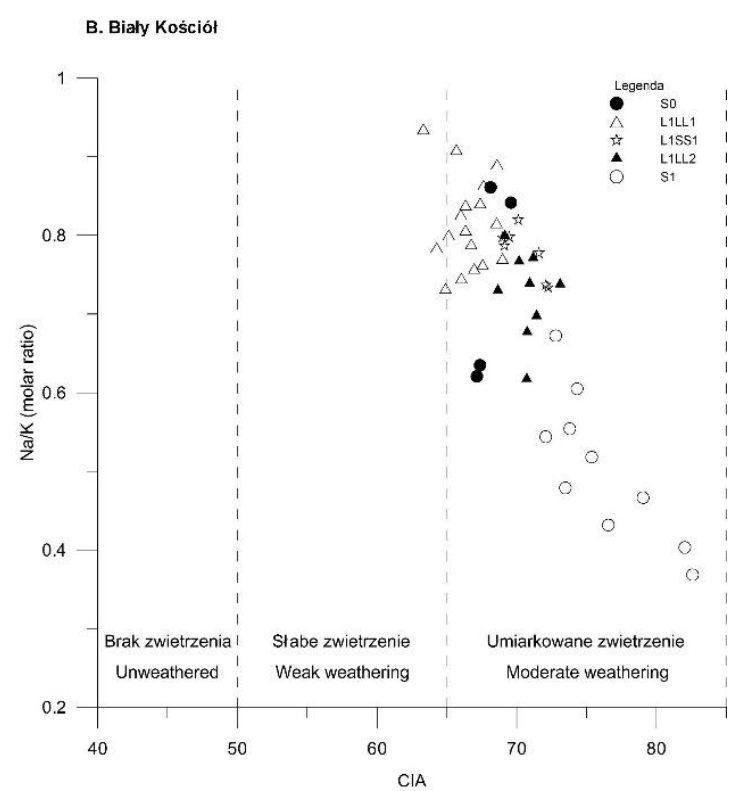

Rys. 6. Stopień zwietrzenia chemicznego ( $\mathrm{Na} / \mathrm{K}$ vs CIA) sekwencji w Tyszowcach i Białym Kościele

The chemical weathering degree $(\mathrm{Na} / \mathrm{K}$ vs CIA) of the sequences in Tyszowce and Biały Kościół

Interpretacja taka wymagałby jednak założenia względnej homogeniczności materiału macierzystego. Dobrym wskaźnikiem heterolub homogeniczności obszarów źródłowych pyłu lessowego może być molowy stosunek Ti/Al, ponieważ powinien być nieczuły na postdepozycyjne procesy wietrzenia chemicznego (Hao i in. 2010) w pH zbliżonym do neutralnego (Sheldon 2006). Tytan i glin są najbardziej niemobilne spośród wszystkich pierwiastków głównych (Broecker, Peng 1982). Wskaźnik Ti/Al często zestawia się z molowym stosunkiem K/Al (Cox i in. 1995), który może być dobrym wskaźnikiem zwietrzenia chemicznego - w Tyszowcach korelacja z CIA wyniosła -0,91 a w Białym Kościele $-0,86$. Stosunek K/Al ponadto jest często używany jako wyznacznik chemicznej dojrzałości osadu, ponieważ jego wartości różnią się znacznie dla wybranych grup minerałów - powyżej wartości 0,3 dominują skalenie, a poniżej minerały ilaste (Cox i in. 1995; Peng $\mathrm{i}$ in. 2016).Wykres K/Al vs Ti/Al (rys. 7) uznaje się za przydatny przy próbach identyfikacji pochodzenia osadów (Peng i in. 2016). W tym przy- padku zastosowano go w celu wykrycia ewentualnej współzależności pomiędzy stopniem zwietrzenia chemicznego a względnym udziałem niemobilnych pierwiastków - w określonych sytuacjach nawet niemobilne pierwiastki mogą być $\mathrm{w}$ pewnym stopniu włączane we wtórne produkty pedogenezy (Taboada i in. 2006).

Wykazano, że w Tyszowcach, i w nieco mniejszym stopniu w Białym Kościele, zaznacza się spadek wartości Ti/Al wraz ze spadkiem wartości $\mathrm{K} / \mathrm{Al}$ (tj. wzrostem stopnia zwietrzenia chemicznego). Oznacza to, że nawet tytan i glin uległy mobilizacji w skali profilu, co uniemożliwia rozważania na temat homo- lub heterogeniczności obszarów źródłowych. Stwierdzić można jedynie, że w rozpatrywanych sekwencjach lessowo-glebowych zbliżony jest zakres wartości Ti/Al, co mogłoby ewentualnie sugerować wspólny obszar źródłowy (lub obszary źródłowe). Wartości K/Al również mieszczą się w wąskim zakresie - w Tyszowcach od 0,168 do 0,296 (średnia 0,247), a w Białym Kościele od 0,121 do 0,219 (średnia 0,176 ) i w obu badanych sekwencjach wyraźnie wskazują przewagę mine- 
rałów ilastych nad minerałami potasowymi (np. skaleniami potasowymi lub łyszczykami). W żadnym wypadku na obecnym etapie badań nie można jednak w wiarygodny sposób wnioskować nie tylko o lokalizacji obszaru badań, ale nawet o jego homogeniczności. Nie można wy- kluczyć istnienia całkowicie odmiennych obszarów źródłowych dla rozpatrywanych sekwencji. W przypadku przyjęcia takiej interpretacji różnice składu chemicznego i stopnia zwietrzenia chemicznego mogłyby wynikać $\mathrm{z}$ różnic tych parametrów na obszarach źródłowych.
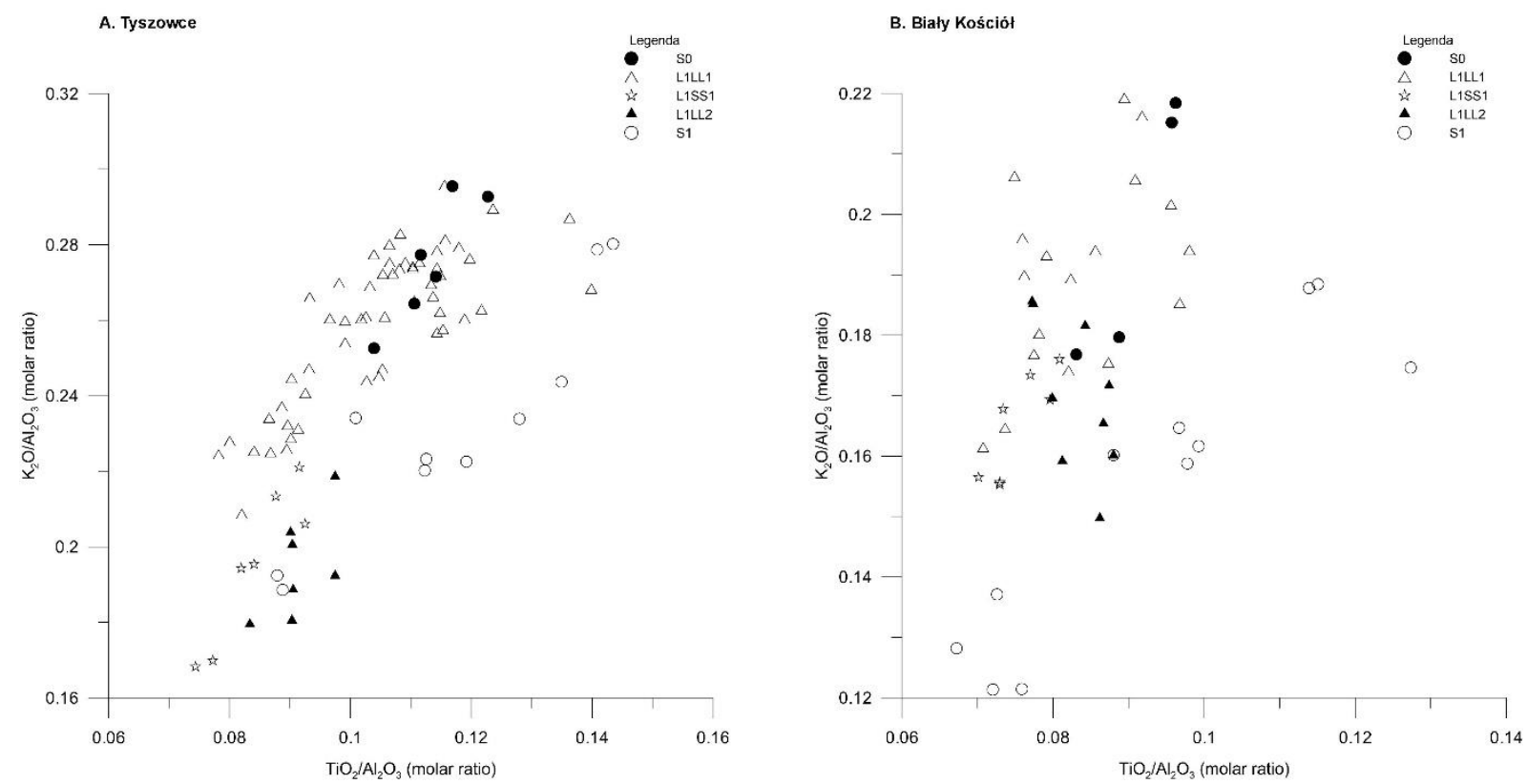

Rys. 7. Wykres K/Al vs Ti/Al sekwencji w Tyszowcach i Białym Kościele

The scatter diagram K/Al vs Ti/Al of the sequences in Tyszowce and Biały Kościól

Kolejną możliwą przyczyną różnic w składzie chemicznym i stopniu zwietrzenia chemicznego jest zróżnicowane tempo depozycji lessów. Skoro obie sekwencje tworzyły się w tym samym czasie, w ciągu ostatniego cyklu interglacjalno-glacjalnego, to mniejsza miąższość wynikać powinna ze słabszej dostawy materiału. Sekwencja lessowo-glebowa jest bezpośrednio infiltrowana przez wody opadowe (Skurzyński i in. 2017) modyfikujące skład chemiczny wskutek interakcji woda-skała. Zasięg infiltracji w lessach, m.in. w zależności od cech litologicznych osadu i wielkości opadu atmosferycznego, według różnych autorów waha się od 2 do $5 \mathrm{~m}$ (np. Tu i in. 2009; Zeng i in. 2016). Ponadto woda, ze względu na powszechne w lessach spękania, może być dosyć szybko transportowana bezpośrednio w głębsze partie profilu (Derbyshire 2001). Możliwe jest zatem, że skład chemiczny 9-metrowej sekwencji w Białym Kościele został bardziej zmodyfikowany wskutek infiltracji niż 19-metrowa sekwencja w Tyszowcach. Pomijając nawet infiltrację, większe tempo depozycji materiału skutkujące większą miąższością lessów L1LL1 skracało zapewne czas eks- pozycji deponowanego materiału na zmienne warunki atmosferyczne, co również może się przejawiać większym udziałem świeżego materiału zasobnego $\mathrm{w}$ mobilne pierwiastki.

\section{Podsumowanie}

Przedstawione rezultaty badań wykazały stratygraficzne i przestrzenne zróżnicowanie składu chemicznego i stopnia zwietrzenia sekwencji lessowo-glebowych reprezentujących dwa skrajnie położone obszary lessowe w Polsce. W obu sekwencjach metoda chemostratygraficzna potwierdziła i uzupełniła wcześniejszą interpretację lito-pedostratygraficzną, wskazującą na istnienie pięciu podstawowych jednostek lessowo-glebowych. Jednostki te pod względem składu chemicznego wykazują wiele charakterystycznych cech wspólnych, pozwalających na korelację między profilami. Oznacza to, że uzasadnione mogą być analizy porównawcze składu chemicznego dwóch oddalonych od siebie sekwencji lessowo-glebowych. 
Istotnym wskaźnikiem różnicującym profile w Tyszowcach i Białym Kościele wydaje się ilościowy charakter zmian składu chemicznego. W Białym Kościele udział pierwiastków związanych z przekształceniami pedogenetycznymi jest znacznie wyższy niż w Tyszowcach, które charakteryzują się wysokim udziałem pierwiastków mobilnych. Przekłada się to na większe zwietrzenie chemiczne sekwencji w Białym Kościele - wskaźnik CIA osiąga wartości typowe dla umiarkowanego wietrzenia chemicznego w ciepłym i wilgotnym klimacie. Jednostki lessowe, w odróżnieniu od gleb, nie mogły jednak kształtować się w warunkach ciepłego i wilgotnego klimatu. Ich wyższy stopień zwietrzenia w Białym Kościele może być związany ze zjawiskiem recyklingu lessów, skutkującym wymieszaniem materiału o różnym stopniu zwietrzenia chemicznego. Interpretacja taka wymagałaby założenia wspólnego obszaru alimentacyjnego i transportu ze wschodu na zachód.

Analiza nie pozwoliła na wiarygodne i pewne wnioskowanie na temat obszarów źródłowych pyłu lessowego, ze względu na dosyć silną pozytywną korelację udziału niemobilnych pierwiastków ze stopniem zwietrzenia chemicznego. Nawet tytan i glin zostały włączone we wtórne produkty pedogenezy. Nie można również wykluczyć odmiennego źródła (lub źródeł) materiału budującego rozpatrywane sekwencje lub że wyższy stopień zwietrzenia chemicznego wynika po prostu $\mathrm{z}$ mniejszej miąższości lessów w Białym Kościele. Mniejsze tempo depozycji mogłoby skutkować istotniejszym przeobrażaniem deponowanego materiału ze względu na dłuższą ekspozycję na zmienne warunki atmosferyczne, infiltrację wód opadowych etc.

Badania zrealizowano $\mathrm{w}$ ramach projektu Narodowego Centrum Nauki nr 2011/01/D/ST10/06049 pt. „Ustalenie chronologii powstania późno-plejstoceńskiej pokrywy lessowej na obszarze Polski na podstawie datowania luminescencyjnego wysokiej rozdzielczości oraz badań lito-pedologicznych wybranych sekwencji lessowo-glebowych" oraz funduszy przeznaczonych na działalność statutową 1015/S/IGiRR/2017 Uniwersytetu Wrocławskiego.

\section{Literatura}

Ahmad I., Chandra R. 2013. Geochemistry of loesspaleosol sediments of Kashmir Valley, India: Provenance and weathering. Journal of Asian Earth Sciences 66: 73-89.
Bokhorst M., Beets C., Marković S., Gerasimenko N., Matviishina Z., Frechen M. 2009. Pedochemical climate proxies in Late Pleistocene Serbian-Ukrainian loess sequences. Quaternary International 198: 113-123.

Broecker W., Peng T. 1982. Tracers in the Sea. Eldigio Press, New York.

Buggle B., Glaser B., Hambach U., Gerasimenko N., Markowić S. 2011. An evaluation of geochemical weathering indices in loess-paleosol studies. Quaternary International 240: 12-21.

Buggle B., Glaser B., Zoller L., Hambach U., Marković S., Glaser I., Gerasimenko N. 2008. Geochemical characterization and origin of Southeastern and Eastern European loesses (Serbia, Romania, Ukraine). Quaternary Science Reviews 27: 1058-1075.

Buraczyński J., Wojtanowicz J. 1975. Nowe profile lessowe Grzędy Sokalskiej. Annales UMCS, sec. B, 28: 1-37.

Cegła J. 1972. Sedymentacja lessów Polski. Acta Universitatis Wratislaviensis 168, Studia Geograficzne 17: 1-72.

Chen Y., Li X., Han Z., Yang S., Wang Y., Yang D. 2008. Chemical weathering intensity and element migration features of the Xiashu loess profile in Zhenjiang, Jiangsu Province. Journal of Geographical Sciences 18: 341-352.

Ciszek D., Jary Z., Kida J., Karamański P. 2001. Profil lessowy w Białym Kościele (Wzgórza Niemczańsko-Strzelińskie). W: Z. Jary, J. Kida (red.) Osady plejstoceńskie przedpola Sudetów, XI Seminarium „Korelacja stratygraficzna lessów i utworów lodowcowych Polski i Ukrainy”, Wrocław-Jarnołtówek 23-28.IX.2001. Instytut Geograficzny UWr.: 58-60.

Cox R., Lowe D., Cullers R. 1995. The influence of sediment recycling and basement composition on evolution of mudrock chemistry in the southwestern United States. Geochimica et Cosmochimica Acta 59,14: 2919-2940.

Derbyshire E. 2001. Geological hazards in loess terrain, with particular reference to the loess regions of China. Earth-Science Reviews 54: 231-260.

Dodonov A.E. 2007. Loess records - Central Asia. W: S. Elias (red.) The Encyclopedia of Quaternary Sciences. Elsevier, Amsterdam:14181429.

Dwucet K. 1999. Litogeneza górnego lessu vistuliańskiego na Wyżynach Polskich i na Nizinie Śląskiej. Prace Naukowe Uniwersytetu Ślaskiego w Katowicach 1792:1-163.

Dwucet K., Śnieszko Z. 1996. Neopleistocene loess cover evolution: an example from the Odonów sedimentary succession (Southern Poland). Biuletyn Peryglacjalny 35: 7-43.

Fedorowicz S. 2005. Korelacja dat TL i OSL próbek z czterech profili lessowych Polski SE i SW. Przeglad Geologiczny 53,11: 1047-1050. 
Fedorowicz S. 2006. Metodyczne aspekty luminescencyjnego oznaczania wieku osadów neoplejstoceńskich Europy Środkowej. Wyd. Uniwersytetu Gdańskiego, Gdańsk:1-156.

Gallet S., Jahn B.M., Torii M. 1996. Geochemical characterization of the Luochuan loess-paleosol sequence, China, and paleoclimatic implications. Chemical Geology 133: 67-88.

Gallet S., Jahn B.M., Van Vliet-Lanoë B., Dia A., Rossello E. 1998. Loess geochemistry and its implications for particle origin and composition of the upper continental crust. Earth and Planetary Science Letters 156: 157-172.

Guan H., Zhu C., Zhu T., Wu L., Li Y. 2016. Grain size, magnetic susceptibility and geochemical characteristics of the loess in the Chaohu lake basin: Implications for the origin, paleoclimatic change and provenance. Journal of Asian Earth Sciences 117: 170-183.

Hao Q., Guo Z., Qiao Y., Xu B., Oldfield F. 2010. Geochemical evidence for the provenance of middle Pleistocene loess deposits in southern China. Quaternary Science Reviews 29: 33173326.

Jahn B.M., Gallet S., Han J. 2001. Geochemistry of the Xining, Xifeng and Jixian sections, Loess Plateau of China: eolian dust provenance and paleosol evolution during the last $140 \mathrm{ka}$. Chemical Geology 178: 71-94.

Jary Z. 2007. Zapis zmian klimatu w górnoplejstoceńskich sekwencjach lessowo-glebowych w Polsce i w zachodniej części Ukrainy. Rozprawy Naukowe Instytutu Geografii i Rozwoju Regionalnego Uniwersytetu Wrocławskiego 1, Wrocław: 1-136.

Jary Z. 2009. Periglacial markers within the Late Pleistocene loess-palaeosol sequences in Poland and western part of Ukraine. Quaternary International 198: 124-135.

Jary Z. 2010. Loess-soil sequences as a source of climatic proxies: an example from SW Poland. Geologija 52,1-4 (69-72): 40-45.

Jary Z., Ciszek D. 2013. Late Pleistocene loesspalaeosol sequences in Poland and western Ukraine. Quaternary International 296: 37-50.

Jary Z., Mroczek P. (red.) 2014. Kukla LOESSFEST '14 - 7th Loess Seminar in Wrocław, International Conference on Loess Research in memoriam of George Kukla, September 8-15 2014. Abstracts and field guidebook. Institute of Geography and Regional Development, University of Wrocław: 1-84.

Jary Z., Ciszek D., Kida J. 2004. Zmiany klimatu zapisane w uziarnieniu lessów Przedgórza Sudeckiego. W: A. Kostrzewski (red.) Geneza, litologia $i$ stratygrafia utworów czwartorzędowych. t. IV, Wydawnictwo Naukowe UAM, Poznań: 137-157.

Jary Z., Ciszek D., Raczyk J., Moska P., Karamański P., Kida J., Korabiewski B. 2014. Biały
Kościół: the key loess section of the NiemczaStrzelin Hills. W: Z. Jary, P. Mroczek (red.) Kukla LOESSFEST '14 - 7th Loess Seminar in Wrocław. International Conference on Loess Research in memoriam of George Kukla, September 8-15 2014. Abstracts and field guide book. Institute of Geography and Regional Development, University of Wrocław: 43-46.

Jary Z., Kida J., Śnihur M. 2002. Lessy i osady lessopochodne w południowo-zachodniej Polsce. Czasopismo Geograficzne 73,1-2: 63-100.

Jary Z., Mroczek P., Moska P., Ciszek D., Raczyk J., Skurzyński J., Krawczyk M., Korabiewski B., Seul C. 2014. Tyszowce loess section: the huge L1L1 loess accumulation and three generations of ice wedge casts. W: Z. Jary, P. Mroczek (red.) Kukla LOESSFEST '14 - 7th Loess Seminar in Wroctaw. International Conference on Loess Research in memoriam of George Kukla, September 8-15 2014. Abstracts and field guidebook. Institute of Geography and Regional Development, University of Wrocław: 68-69.

Jeong G., Hillier S., Kemp R. 2008. Quantitative bulk and single-particle mineralogy of a thick Chinese loess-paleosol section: implications for loess provenance and weathering. Quaternary Science Reviews 27: 1271-1287.

Jersak J. 1973. Litologia i stratygrafia lessu wyżyn południowej Polski. Acta Geographica Lodziensia 32: 1-142.

Kemp R.A. 2001. Pedogenic modification of loess: significance for palaeoclimatic reconstructions. Earth-Science Reviews 54: 145-156.

Komar M., Łanczont M., Madeyska T. 2009. Spatial vegetation patterns based on palynological records in the loess area between the Dnieper and Odra Rivers during the last interglacialglacial cycle. Quaternary International 198: 152-172.

Kondracki J. 2002. Geografia regionalna Polski. Wydawnictwo Naukowe PWN. Warszawa.

Kraus M. 1999. Paleosols in clastic sedimentary rocks: their geologic applications. EarthScience Reviews 47: 41-70.

Kukla G. 1970. Correlation between loesses and deep-sea sediments. Geologiske Foreningen Foerhandlingar 92: 148-180.

Kukla G. 1975. Loess Stratigraphy of Central Europe. W: K.W. Butzer G. Isaac (red.) After the Australopithecines. Mouton Publishers, The Hague: 99-188.

Kukla G. 1977. Pleistocene Land-Sea Correlations I. Europe. Earth-Science Reviews 13: 307-374.

Kukla G. 1987. Loess stratigraphy in central China. Quaternary Science Reviews 6: 191-219.

Kukla G., An S. 1989. Loess stratigraphy in central China. Palaeogeography, Palaeoclimatology, Palaeoecology 72: 203-225. 
Łącka B., Łanczont M., Madeyska T., Boguckyj A. 2007. Geochemical composition of Vistulian loess and micromorphology of interstadial palaeosol sat the Kolodiiv site (East Carpathian Foreland, Ukraine). Geological Quarterly 51(2): 127-146.

Łanczont M., Madeyska T., Bogucki A., Mroczek P., Hołub B., Łącka B., Fedorowicz S., Nawrocki J., Frankowski Z., Standzikowski K. 2015a. Środowisko abiotyczne paleolitycznej ekumeny strefy pery- i metakarpackiej. W: M. Łanczont, T. Madeyska (red.) Paleolityczna ekumena strefy pery- $i$ meta karpackiej. Wydawnictwo UMCS, Lublin: 55-457.

Łanczont M., Madeyska T., Mroczek P., Komar M., Łącka B., Bogucki A., Sobczyk K., Wilczyński J. 2015b. The loess-palaeosol sequence in the Upper Palaeolithic site at Kraków Spadzista - a palaeoenvironmental approach. Quaternary International 365: 98-113.

Łukaszew W., Mojski J.E. 1968. Badania geochemiczne lessów Wyżyny Lubelskiej. Kwartalnik Geologiczny 12,4: 966-982.

Marković S., Bokhorst M., Vanderberghe J., McCoy W., Oches E., Hambach U. 2008. Late Pleistocene loess-paleosol sequences in the Vojvodina region, north Serbia. Journal of Quaternary Science 23: 73-84.

Marković S., Stevens T., Kukla G.J., Hambach U., Fitzsimmons K.E., Gibbard P., Buggle B., Zech M., Guo Z., Hao Q., Wu H., Ken O’Hara D., Smalley J., Ujvari G., Sümegi P., TimarGabor A., Veres D., Sirocko F., Vasilijević A., Jary Z., Svensson A., Jović V., Lehmkuhl F., Kovacs J., Svircev Z. 2015. Danube loess stratigraphy - Towards a pan-European loess stratigraphic model. Quaternary Science Reviews 148: 228-258.

Martinson D.G., Pisias N.G., Hays J.D., Imbrie J., Moore T.C.Jr., Shackleton N.J. 1987. Age Dating and the Orbital Theory of the Ice Ages: Development of a High-Resolution 0 to 300,000-Year Chronostratigraphy. Quaternary Research 27: 1-29.

Maruszczak H. 1972. Wyżyny Lubelsko-Wołyńskie. W: M. Klimaszewski (red.) Geomorfologia Polski, t. 1, Warszawa.

Maruszczak H. 1974. Gleby kopalne i stratygrafia lessów Grzędy Sokalskiej. Annales UMCS, sec. B 26: 27-66.

Maruszczak H. 1976. Stratygrafia lessów Polski południowo-wschodniej. Biuletyn Instytutu Geologicznego 297: 135-175.

Maruszczak H. 1991a. Ogólna charakterystyka lessów w Polsce. W: H. Maruszczak (red.) Podstawowe profile lessów w Polsce. Wyd. UMCS, Lublin, A: 1-12.

Maruszczak H. 1991b. Zróżnicowanie stratygraficzne lessów polskich. W: H. Maruszczak (red.)
Podstawowe profile lessów w Polsce. Wyd. UMCS, Lublin, A: 13-35.

McLennan S. 1993. Weathering and global denudation. Journal of Geology 101: 295-303.

Moska P., Adamiec G., Jary Z. 2011. OSL Dating and lithological characteristics of Loess deposits from Biały Kościół. Geochronometria 38 (2): 162-171.

Moska P., Adamiec G., Jary Z. 2012. High resolution dating of loess profile from Biały Kościół, south-west Poland. Quaternary Geochronology 10: 87-93.

Moska P., Adamiec G., Jary Z., Bluszcz A. 2017. OSL chronostratigraphy for loess deposits from Tyszowce - Poland. Geochronometria DOI: 10.1515/geochr-2015-0074, w druku.

Moska P., Jary Z., Adamiec G., Bluszcz A. 2014. Preliminary OSL dating results for loess deposits from Tyszowce. W: Z. Jary, P. Mroczek (red.) Kukla LOESSFEST '14 - 7th Loess Seminar in Wroctaw. International Conference on Loess Research in memoriam of George Kukla, September 8-15 2014. Abstracts and field guidebook. Institute of Geography and Regional Development, University of Wroclaw: 38.

Mroczek P. 2013. Recycled loesses - A micromorphological approach to the determination of local source areas of Weichselian loess. Quaternary International 296: 241-250.

Muhs D.R. 2007. Loess deposits, origins, and properties. W: S. Elias (red.) The Encyclopedia of Quaternary Sciences. Elsevier, Amsterdam: 1405-1418.

Muhs D.R. 2013. The geologic records of dust in the Quaternary. Aeolian Research 9: 3-48.

Muhs D.R., Bettis III E.A. 2000. Geochemical variations in Peoria Loess of western Iowa indicate paleowinds of midcontinental North America during last glaciation. Quaternary Research 53: 49-61.

Muhs D.R., Ager T.A., Beget J.E.2001. Vegetation and paleoclimate of the last interglacial period, central Alaska. Quaternary Science Reviews 20: 41-61.

Muhs D.R., Ager T.A., Bettis III E.A., McGeehin J., Been J.M., Beget J.E., Pavich M.J., Stafford Jr. T.W., Stevens D.S.P. 2003. Stratigraphy and palaeoclimatic significance of Late Quaternary loess-palaeosol sequences of the Last Interglacial-Glacial cycle in central Alaska. Quaternary Science Reviews 22: 1947-1986.

Muhs D.R., Ager T.A., Skipp G., Beann J., Budahn J., McGeehin J.P. 2008. Paleoclimatic significance of chemical weathering in loess-derived paleosols of Subarctic Central Alaska. Arctic, Antarctic and Alpine Research 40: 396-411.

Nesbitt H.W., Young G.M. 1982. Early proterozoic climate and plate motions inferred from major 
element chemistry of lutites. Nature 229: 715 717.

Nesbitt H.W., Young G.M. 1984. Prediction of some weathering trends of plutonic and volcanic rocks based on thermodynamic and kinetic considerations. Geochimica and Cosmochimica Acta 48: 1523-1534.

Peng S., Hao Q., Wang L., Ding M., Zhang W., Wang Y., Guo Z. 2016. Geochemical and grain-size evidence for the provenance of loess deposits in the Central Shandong Mountains region, northern China. Quaternary Research 85: 290-298.

Pisias N.G., Martinson D.G., Moore T.C.Jr., Shackelton N.J., Prell W., Hays J., Boden G. 1984. High resolution stratigraphic correlation of benthic oxygen isotopic records spanning the last 300,000 years. Marine Geology 56: 119136.

Porter S.C. 2007. Loess records - China. In: S. Elias (red.) The Encyclopedia of Quaternary Sciences. Elsevier, Amsterdam: 1429-1440.

Pye K. 1995. The nature, origin and accumulation of loess. Quaternary Science Reviews 14: 653667.

Pye K., Johnson R. 1988. Stratigraphy, geochemistry, and thermoluminescence ages of Lower Mississippi Valley loess. Earth Surface Processes and Landforms 13: 103-124.

Raczyk J., Jary Z., Korabiewski B. 2015. Geochemical properties of the Late Pleistocene loess-soil sequence in Dankowice (Niemcza-Strzelin Hills). Landform Analysis 29: 49-61.

Rousseau D.D., Derbyshire E., Antoine P., Hatte 2007. Loess records - Europe. W: S. Elias (red.) The Encyclopedia of Quaternary Sciences. Elsevier, Amsterdam: 1440-1456.

Shao J., Yang S., Li C. 2012. Chemical indices (CIA and WIP) as proxies for integrated chemical weathering in China: inferences from analysis of fluvial sediments. Sedimentary Geology 265-266: 110-120.

Sheldon N. D. 2006. Abrupt chemical weathering increase across the Permian-Triassic boundary. Palaeogeography, Palaeoclimatology, $\mathrm{Pa}$ laeoecology 231: 315-321.

Skurzyński J., Modelska M., Raczyk J., Staśko S., Jary Z. 2017. Skład chemiczny wód porowych późnoplejstoceńskiej sekwencji lessowo-glebowej w Zaprężynie (SW Polska). Przegląd Geologiczny 65,11/2: 1383-1387.

Song Y., Chen X., Qian L., Li C., Li Y., Li X. 2014. Distribution and composition of loess sediments in the Ili Basin, Central Asia. Quaternary International 334-335: 61-73.

Taboada T., Cortizas A., Garcia C., Garcia-Rodeja E. 2006. Particle-size fractionation of titanium and zirconium during weathering and pedogenesis of granitic rock in NW Spain. Geoderma 131: 218-236.
Taylor S.R., McLennan S.M. 1985. The Continental Crust: Its Composition and Evolution. Blackwell, Oxford: 1-312.

Taylor S.R., McLennan S.M., McCulloch M.T. 1983. Geochemistry of loess, continental crustal composition and crustal model ages. Geochimica et Cosmochimica Acta 47: 1897-1905.

Tu X.B., Kwong A.K.L., Dai F.C., Tham L.G., Min H. 2009. Field monitoring of rainfall infiltration in a loess slope and analysis of failure mechanism of rainfall-induced landslides. Engineering Geology 105: 134-150.

Tugulan L.C., Duliu O.G., Bojar A.-V., Dumitras D., Zinicovskaia I., Culicov O. A., Frontasyeva M.V. 2016. On the geochemistry of the Late Quaternary loess deposits of Dobrogea (Romania). Quaternary International 399: 100110.

Ujvari G., Varga A., Balogh-Brunstad Z. 2008. Origin, weathering and geochemical composition of loess in southwestern Hungary. Quarterly Research 69: 421-437.

Van Loon A. J. 2006. Lost loesses. Earth-Science Reviews 74: 309-316.

Wojtanowicz J., Buraczyński J. 1978. Materiały do chronologii bezwzględnej lessów Grzędy Sokalskiej. Annales UMCS sec. B 30/31: 37-54.

Yang S., Ding F., Ding Z. 2006. Pleistocene chemical weathering history of Asian arid and semi-arid regions recorded in loess deposits of China and Tajikistan. Geochimica et Cosmochimica Acta 70: 1695-1709.

Yang S., Li C., Yang D., Li X. 2004. Chemical weathering of the loess deposits in the lower Changjiang Valley, China, and paleoclimatic implications. Quaternary International 117: 27-34.

Zeng R.Q., Meng X.M., Zhang F.Y., Wang S.Y., Cui Z.J., Zhang M.S., Zhang Y., Chen G. 2016. Characterizing hydrological processes on loess slopes using electrical resistivity tomography - A case study of the Heifangtai Terrace, Northwest China. Journal of Hydrology 541, part B: 742-753.

\section{Summary}

The results of the research show the stratigraphical and spatial differentiation of the chemical composition and the degree of the weathering of loess-paleosol sequences representing two distant loess areas in Poland. In both profiles, the chemostratigraphic method confirmed and verified the earlier litho-pedostratigraphic interpretation, indicating the existence of five basic loesssoil units. These units have a number of common characteristics in terms of chemical composition, allowing for a correlation between profiles. We 
think that a comparative analysis of the chemical composition of the two distant loess-paleosol sequences is justified.

It is clearly visible that the quantitative nature of the changes in chemical composition is a significant indicator of the differentiation of the profiles in Tyszowce and Biały Kościół. In Biały Kościól, the amount of the elements related to pedogenetic transformations is much higher than in Tyszowce, which is characterized by a high contribution of mobile elements. For this reason, the degree of chemical weathering of the sequence in Biały Kościół is much higher - the CIA index (chemical index of alteration) reaches values typical for moderate chemical weathering in warm and humid climate. However, it is unlikely that loess units develop in warm and humid climate, as opposed to soils. The phenomenon of loess recycling appears to better explain the higher degree of chemical weathering in Biały Kościół as a result of a higher contribution of stronger-weathered dust particles eroded and transported from older loess covers. Such an interpretation requires the assumption of a common source area and transport direction from east to west. The analysis did not allow for reliable and certain inference about the source areas of loess dust, due to the relatively strong positive correlation of the amount of non-mobile elements with the degree of chemical weathering. Even titanium and aluminum have been incorporated into secondary products of pedogenesis.

The results of the analysis enabled us to exclude the different sources of the loess material. Alternatively, the higher rate of chemical weathering may also be caused by a lower thickness of the loess in Biały Kościół. A lower thickness of the loess cover, suggesting a lower rate of deposition, may result in a more significant change of the deposited material due to longer exposure to variable atmospheric conditions, rainwater infiltration, etc. 